\title{
Low Density Lipoprotein Cholesterol: An Association with the Severity of Diabetic Retinopathy
}

\author{
T.L. Dornan ${ }^{1}$, R. D. Carter ${ }^{1}$, A. J. Bron ${ }^{2}$, R. C. Turner ${ }^{1}$ and J. I. Mann ${ }^{1}$ \\ ${ }^{1}$ Diabetes Research Laboratories, and ${ }^{2}$ Nuffield Laboratory of Ophthalmology, Radcliffe Infirmary, Oxford, UK
}

Summary. Diurnal profiles of total and lipoprotein cholesterol and triglycerides were measured in 11 insulin-dependent diabetic subjects without retinopathy, 10 with background and 10 with proliferative retinopathy. The groups were closely matched for age and duration of diabetes. Total cholesterol levels were higher in patients with proliferative $(5.6 \pm 0.5 \mathrm{mmol} / \mathrm{l})$ than background $(5.1 \pm$ $0.7 \mathrm{mmol} / 1)$ or no retinopathy $(4.6 \pm 0.8 \mathrm{mmol} / \mathrm{l}$, trend test; $p<0.003$ ), due to raised levels of low density lipoprotein (LDL) cholesterol $(3.8 \pm 0.9,3.2 \pm$ 0.6 and $2.8 \pm 0.8 \mathrm{mmol} / 1$ respectively; $p<0.02$ ). High density lipoprotein (HDL) levels were similar in patients with and without retinopathy and HDL/ LDL ratios were lower with more severe retinopathy $(p<0.025)$. Cholesterol levels were similar in diabetic subjects without retinopathy and in 12 normal subjects. Triglyceride levels were not related to retinopathy and no measure of plasma lipids correlated with $\mathrm{HbA}_{1}$ or 24-h mean plasma glucose. Total and LDL cholesterol were weakly inversely correlated with creatinine clearance but the association with retinopathy was independent of this effect.

Key words: Diabetes, lipids, diabetic retinopathy, cholesterol, triglycerides, diabetic nephropathy.

Abnormal levels of plasma lipids and lipoproteins are found in many diabetic patients and relate to blood glucose control in insulin-dependent diabetes [1-4]. Higher levels of lipids have been found in patients with retinopathy than in those without [1,5-10], suggesting that they may play a part in its development, but other workers have been unable to confirm this relationship [11-16]. These discrepancies may have been due to inadequate matching of patient groups for age and treatment type and failure to take into account the effect of renal impairment on plasma lipids [1]. There is significant diurnal variation of plasma cholesterol in diabetic subjects $[17,18]$ which might also obscure such an association. In this study diurnal profiles of cholesterol and its lipoprotein fractions and triglycerides were measured in matched groups of insulin-dependent diabetic patients with different grades of severity of retinopathy and in non-diabetic subjects.

\section{Patients and Methods}

Thirty-one male insulin treated diabetic patients, all of whom had developed diabetes before the age of 36 years, were recruited from medical and ophthalmic clinics and gave written consent to take part in the study. Eleven had no retinopathy on ophthalmoscopy and either no retinopathy or less than five microaneurysms in a standard $13^{\circ}$ macular-based field on fluorescein angiography. Ten had definite background retinopathy (haemorrhages with or without exudates) on ophthalmoscopy, but no new vessels on fluorescein angiography and 10 had severe proliferative retinopathy requiring photocoagulation. Patients with advanced nephropathy (plasma creatinine $>175 \mu \mathrm{mol} / 1$ ) or intermittent claudication were excluded; one patient with proliferative retinopathy had angina but no other patient had symptoms or cardiographic evidence of ischaemic heart disease and no patient had more than one absent foot pulse. The groups were matched as closely as possible for age, duration of diabetes and percentage ideal body weight [19]. The patients had all been prescribed a conventional diabetic diet with $40 \%-50 \%$ of dietary calories taken as carbohydrate; no specific advice had been given for them to take polyunsaturated fats in preference to animal fats or to increase the dietary content of fibre. Twelve healthy male non-diabetic subjects were also studied, similar in age and body weight to the diabetic patients.

The patients were admitted at $17.30 \mathrm{~h}$ for a $24 \mathrm{~h}$ metabolic profile. A Teflon cannula was placed in a forearm vein under local anaesthesia and kept patent by flushing with small volumes of saline solution. The patients were given a diet as close as possible to their home diet, insulin doses were given as usual in relation to meals and they were encouraged to take light exercise during the $24 \mathrm{~h}$ period. Blood was taken with minimal occlusion at 17.30 , 
Table 1. Clinical details of all subjects studied

\begin{tabular}{|c|c|c|c|c|c|c|c|c|c|c|}
\hline & $\begin{array}{l}\text { No. of } \\
\text { subjects }\end{array}$ & $\begin{array}{l}\text { Age } \\
\text { (years) }\end{array}$ & $\begin{array}{l}\text { Duration } \\
\text { of } \\
\text { diabetes } \\
\text { (years) }\end{array}$ & $\begin{array}{l}\text { Body } \\
\text { weight } \\
(\mathrm{kg})\end{array}$ & $\begin{array}{l}\text { Percentage } \\
\text { ideal body } \\
\text { weight }\end{array}$ & $\begin{array}{l}\text { Prevalence } \\
\text { of smokers } \\
(\%)\end{array}$ & $\begin{array}{l}\text { Diastolic } \\
\text { blood } \\
\text { pressure } \\
(\mathrm{mmHg})\end{array}$ & $\begin{array}{l}\text { Insulin dose } \\
\text { (units/kg } \\
\text { body weight) }\end{array}$ & $\begin{array}{l}\mathrm{HbA}_{1} \\
(\%)\end{array}$ & $\begin{array}{l}\text { Mean } \\
\text { plasma } \\
\text { glucose } \\
(\mathrm{mmol} / 1)\end{array}$ \\
\hline $\begin{array}{l}\text { Without } \\
\text { retinopathy }\end{array}$ & 11 & $40 \pm 10$ & $18 \pm 7$ & $74 \pm 6$ & $101 \pm 6$ & $7(64 \%)$ & $79 \pm 8$ & $0.90 \pm 0.30$ & $11.2^{\mathrm{a}} \pm 2.0$ & $7.6 \pm 2.7$ \\
\hline $\begin{array}{l}\text { Background } \\
\text { retinopathy }\end{array}$ & 10 & $40 \pm 11$ & $20 \pm 5$ & $72 \pm 11$ & $105 \pm 12$ & $3(30 \%)$ & $82 \pm 9$ & $0.89 \pm 0.28$ & $12.5 \pm 1.7$ & $9.7 \pm 4.0$ \\
\hline $\begin{array}{l}\text { Proliferative } \\
\text { retinopathy }\end{array}$ & 10 & $42 \pm 8$ & $24 \pm 4$ & $75 \pm 7$ & $111 \pm 14$ & $5(50 \%)$ & $84 \pm 7$ & $0.89 \pm 0.15$ & $12.5 \pm 1.2$ & $8.9 \pm 3.1$ \\
\hline Normal subjects & 12 & $41 \pm 12$ & - & $72 \pm 9$ & $108 \pm 11$ & - & $81 \pm 15$ & - & - & - \\
\hline
\end{tabular}

Results expressed as mean $\pm \mathrm{SD}$. ${ }^{\mathrm{a}} p<0.025$ compared with both groups with retinopathy

Table 2. Mean plasma lipid concentrations

\begin{tabular}{llllllc}
\hline & $\begin{array}{l}\text { No. of } \\
\text { subjects }\end{array}$ & $\begin{array}{l}\text { Total } \\
\text { cholesterol } \\
(\mathrm{mmol} / \mathrm{l})^{\mathrm{a}}\end{array}$ & $\begin{array}{l}\text { LDL } \\
\text { cholesterol } \\
(\mathrm{mmol} / \mathrm{l})^{\mathrm{b}}\end{array}$ & $\begin{array}{l}\text { HDL } \\
\text { cholesterol } \\
(\mathrm{mmol} / \mathrm{l})\end{array}$ & $\begin{array}{l}\text { HDL/LDL } \\
\text { ratio }^{\mathrm{c}}\end{array}$ & $\begin{array}{c}\text { Triglycerides } \\
(\mathrm{mmol} / \mathrm{l})\end{array}$ \\
\hline Without retinopathy & 11 & $4.6 \pm 0.8$ & $2.8 \pm 0.8$ & $1.3 \pm 0.3$ & $0.50 \pm 0.20$ & $1.7 \pm 0.9$ \\
Background retinopathy & 10 & $5.1 \pm 0.7$ & $3.2 \pm 0.6$ & $1.3 \pm 0.3$ & $0.41 \pm 0.13$ & $2.0 \pm 0.8$ \\
Proliferative retinopathy & 10 & $5.6 \pm 0.5$ & $3.8 \pm 0.9$ & $1.2 \pm 0.3$ & $0.34 \pm 0.12$ & $1.7 \pm 0.7$ \\
Normal subjects & 12 & $4.5 \pm 0.6$ & $2.5 \pm 0.6$ & $1.3 \pm 0.3$ & $0.56 \pm 0.22$ & $1.8 \pm 0.9$ \\
\hline
\end{tabular}

Results expressed as mean $\pm \mathrm{SD}$

Trend within diabetic patients: ${ }^{\mathrm{a}} p<0.003 ;{ }^{\mathrm{b}} p<0.02 ;{ }^{\mathrm{c}} p<0.025$

$20.00,01.00,03.00,05.00,08.00,10.30,12.30,14.30$ and $16.30 \mathrm{~h}$ for lipid assays. Fasting blood was taken for $\mathrm{Hb}_{1}$ assay. Samples were taken hourly during the day and 2-hourly overnight for glucose estimation and a $24 \mathrm{~h}$ urine collection taken for measurement of protein and creatinine clearance.

Glucose was determined by glucose oxidase (GOD Perid Kit, Boehringer Corporation, Mannheim FRG) and triglycerides by enzymatic hydrolysis using a kit (Boehringer Corporation) and automated spectrophotometer. Cholesterol was measured with an autoanalyser (Technicon AA1) and cholesterol in the lipoprotein fractions by standard precipitation techniques as described previously [18]. $\mathrm{HbA}_{1}$ was measured by column chromatography [20] (normal range: $5.1 \%-8.6 \%$ ). Creatinine was measured by multichannel analyser (Vickers M300).

From the 10 measurements of triglycerides, total cholesterol and lipoprotein cholesterol on each patient, individual mean values were calculated. The $24 \mathrm{~h}$ plasma glucose areas $\left(\mathrm{mmol} \mathrm{l}^{-1} \mathrm{~min}^{-1}\right)$ were computed from the plasma glucose levels using linear interpolation between assay results and mean plasma glucose levels $(\mathrm{mmol} / \mathrm{l})$ were calculated by dividing by the time base. Statistical analysis was by permutational test for trend, Mann-Whitney $U$ test and linear correlation analysis. Results are given as mean \pm SD.

\section{Results}

Clinical details of all subjects, mean $\mathrm{HbA}_{1}$ and mean plasma glucose levels are shown in Table 1. Mean $\mathrm{HbA}_{1}$ was higher in all patients with retinopathy than those without ( $p<0.025$ ), but there were no significant differences in plasma glucose.

Cholesterol and triglyceride results are shown in Table 2. Mean total plasma cholesterol increased with the severity of retinopathy $(p<0.003$, trend test). A similar trend was seen in LDL cholesterol $(p<0.02$, trend test), but HDL cholesterol levels were similar in all groups. The ratio of HDL to LDL cholesterol was therefore lowest in patients with proliferative and highest in those with no retinopathy $(p<0.025$, trend test). Mean triglyceride levels were similar in all groups. There were no differences between the patients without retinopathy and control subjects. There was no significant correlation in the diabetic subjects between any lipid measurement and age, duration of diabetes, percentage ideal body weight, diastolic blood pressure, $\mathrm{HbA}_{1}$ or mean plasma glucose.

Renal function in the patient groups is shown in Table 3. Mean creatinine clearance was lowest and the prevalence of significant proteinuria highest in patients with proliferative retinopathy. There was a weak, but statistically significant inverse correlation between creatinine clearance and total cholesterol $(y=-0.014 x+6.5$ where $y$ is cholesterol and $x$ is creatinine clearance; $r=-0.44, n=30, p<0.05$ ) 
Table 3. Creatinine clearance. Prevalence of significant proteinuria and total and LDL cholesterol concentration adjusted to a creatinine clearance of $100 \mathrm{ml} / \mathrm{min}$

\begin{tabular}{|c|c|c|c|c|}
\hline & $\begin{array}{l}\text { Creatinine clearance } \\
(\mathrm{ml} / \mathrm{min})^{\mathrm{a}}\end{array}$ & $\begin{array}{l}\text { No. of patients } \\
\text { with proteinuria } \\
(>200 \mathrm{mg} / 24 \mathrm{~h})(\%)\end{array}$ & $\begin{array}{l}\text { Adjusted } \\
\text { total cholesterol } \\
(\mathrm{mmol} / 1)^{\mathrm{b}}\end{array}$ & $\begin{array}{l}\text { Adjusted } \\
\text { LDL cholesterol } \\
(\mathrm{mmol} / \mathrm{l})^{\mathrm{b}}\end{array}$ \\
\hline Without retinopathy & $113 \pm 22$ & $1(9 \%)$ & $4.7 \pm 0.8$ & $3.0 \pm 0.8$ \\
\hline Background retinopathy & $104 \pm 22$ & $1(10 \%)$ & $5.2 \pm 0.6$ & $3.3 \pm 0.6$ \\
\hline Proliferative retinopathy & $85 \pm 25$ & $4(40 \%)$ & $5.4 \pm 0.7$ & $3.8 \pm 1.0$ \\
\hline
\end{tabular}

Results expressed as mean $\pm \mathrm{SD}$

Trend within diabetic subjects: ${ }^{\mathrm{a}} p<0.025 ;{ }^{\mathrm{b}} p<0.05$

and LDL cholesterol $(y=-0.012 x+4.5$ where $y$ is LDL and $x$ is creatinine clearance; $r=-0.34, n=$ $30, p=0.05$ ). Although these relationships were weak, they tended to bias the results of the study, therefore the regression equations were used to adjust total and LDL cholesterol to a standard creatinine clearance of $100 \mathrm{ml} / \mathrm{min}$. The mean adjusted values are shown in Table 3 ; the trend towards higher cholesterol with increasing severity of retinopathy remained statistically significant following this adjustment.

\section{Discussion}

These findings suggest that raised levels of LDL cholesterol, or a reduced ratio of HDL to LDL cholesterol, might play a part in the pathogenesis of diabetic retinopathy. However, proof could only come from a prospective study since disturbed lipid metabolism might be a consequence rather than a cause of microangiopathy. The minor clinical differences between groups are unlikely to have influenced the results significantly since neither diabetes duration, body weight nor blood pressure correlated significantly with cholesterol concentrations. Renal impairment, which is common in diabetic patients with retinopathy [21], tended to increase cholesterol levels. However, LDL cholesterol remained significantly correlated with retinopathy despite adjustment to a standard creatinine clearance. It seems improbable that the association between cholesterol and retinopathy was secondary to the minor differences in diabetic control: poor diabetic control is associated more with hypertriglyceridaemia and hypercholesterolaemia [4], and there was no correlation between lipid concentrations and levels of $\mathrm{HbA}_{1}$ or glucose. It is perhaps surprising that we did not find a relationship between control and triglyceride concentrations. The degree of hyperglycaemia in these patients may not have been sufficient to alter levels appreciably.
The relationship between plasma lipids and retinopathy has practical importance since lipid-lowering agents might be beneficial for retinopathy. Most clinical trials studied patients with severe exudative retinopathy and showed no effect on visual prognosis $[14,17,22-25]$. One report suggested that a diet rich in polyunsaturated fats delayed the progression of retinopathy [26], but the criteria for progression and the extent of the difference between groups were not stated. The role of cholesterol in the pathogenesis of retinopathy deserves further study. Lipid-lowering at an early stage of diabetes might delay or prevent the progression of microangiopathy.

Acknowledgements. We are grateful to the Wellcome Trust and Novo Research Institute who funded the study, C. Peckar and D. Barbour for ophthalmic help, M. Beeton and P. Jones for nursing care, R. Sargent and R. Rolph for preparing the diets, C. Whittle and P. Poon for $\mathrm{HbA}_{1}$ assay, D. Jelphs and R. Mullins for lipid assays, P. Passant in the Nuffield Department of Clinical Biochemistry for the creatinine assays and L.Hoffman and A. Reeve for preparing the manuscript.

\section{References}

1. Keiding NR, Mann GV, Root HF, Lawry EY, Marble A (1952) Serum lipoproteins and cholesterol levels in normal subjects and in young patients with diabetes in relation to vascular complications. Diabetes $1: 434-440$

2. Adlersber D, Eisler L (1959) Circulating lipids in diabetes mellitus. JAMA 170: 1261-1265

3. Schrade W, Boehle E, Biegler R, Harmuth E (1963) Fatty acid composition of lipid fractions in diabetic serum. Lancet 1: 285-290

4. Mann JI, Hughson WG, Holman RR, Honour AJ, Thorogood M, Smith A, Baum JD (1978) Serum lipids in treated diabetic children and their families. Clin Endocrinol 8:27-33

5. lannaccone A, Kornerup T (1954) Plasma lipids and diabetic retinopathy. Acta Med Scand 148:411-416

6. Adlersberg D, Wang CI, Rifkin H, Berkman J, Ross G, Weinstein $C$ (1956) Serum lipids and polysaccharides in diabetes mellitus. Diabetes 5: 116-120

7. Esmann V, Lundbaek K, Madsen PH (1963) Types of exudates in diabetic retinopathy. Acta Med Scand 174:375-384

8. Kissebah AH, Siddiq YK, Kohner EM, Lowy C, Lewis B, Fra- 
ser TR (1975) Plasma-lipids and glucose insulin relationship in non-insulin requiring diabetics with and without retinopathy. Lancet $1: 1104-1107$

9. Constable IJ, Welborn TA, Cooper RL, McCann VJ, Stanton KM, Greer DV, Stein G, Sebastian P (1980) Medical correlates and diabetic retinopathy screening. Trans Ophthalmol Soc UK 100:78-82

10. Job D, Eschwege E, Tchobroutsky G, Guyot-Argenton C, Aubry JP, Derot N (1975) Diabetic retinopathy, duration of diabetes and risk factors of atherosclerotic cardiovascular disease. Acta Diabetol Lat 12: 1-8

11. Petersen VP (1953) Interrelationships of individual plasma phospholipids and cholesterol in health and long-term diabetes mellitus. Acta Med Scand 146: 375-383

12. New MI, Roberts TN, Bierman EL, Reader GG(1963) The significance of blood lipid alterations in diabetes. Diabetes 12 : 208-212

13. Allbrink MJ, Lavietes PH, Man EB (1963) Vascular disease and serum lipids in diabetes mellitus. Ann Intern Med 58: 305-323

14. Duncan LJP, Cullen JF, Ireland JT, Nolan J, Clarke BF, Oliver MF (1968) A three-year trial of Atromid therapy in exudative diabetic retinopathy. Diabetes 17:458-467

15. Hart A, Thorp JM, Cohen H(1971) Lipoprotein and fibrinogen studies in diabetes. Postgrad Med J (Suppl): 435-439

16. West KM, Erdreich LJ, Stober JA (1980) A detailed study of risk factors for retinopathy and nephropathy in diabetes. Diabetes 29: $501-508$

17. Van Eck WF (1959) The effect of a low fat diet on the serum lipids in diabetes and its significance in diabetic retinopathy. Am J Med 27: 196-211

18. Simpson RW, Carter RD, Moore RA, Penfold WAF (1980) Diurnal changes in plasma lipoproteins in normal subjects and diabetics. Diabetologia 18:35-40
19. Metropolitan Life Insurance Company (1959) Stat Bull Metropol Life Insur Co 40: 1-4

20. Kynoch PAM, Lehman H (1977) Rapid estimation (21/2hours) of glycosylated haemoglobin for routine purposes. Lancet $2: 16$

21. Pirart J (1977) Diabète et complications dégénératives. Présentation d'une etude prospective portant sur 4400 cas observes entre 1947 et 1973. Diabete Metab 3: 173-182

22. Ernest I, Linner E, Svanborg A (1965) Carbohydrate-rich, fatpoor diet in diabetes. Am J Med 39:594-600

23. King RC, Dobree JH, Kok D'A, Foulds WS, Dangerfield WG (1963) Exudative diabetic retinopathy: spontaneous changes and effects of a corn oil diet. Br J Ophthalmol 47: 666-672

24. Esman V, Jensen HJ, Lundbaek K (1963) Disappearance of waxy exudates in diabetic retinopathy during administration of p-amino-salicylate. Acta Med Scand 174: 99-104

25. Houtsmuller AJ (1967) Treatment of exudative diabetic retinopathy with 'Atromid-S'. A double-blind study. In: Ostman J, Hales CN, Milner RDG (eds) Proc 6th Cong Int Diab Fed, Stockholm. Excerpta Med Int Congr Ser No 140: 12

26. Houtsmuller AJ, Zahn KJ, Henkes HE (1979) Unsaturated fats and progression of diabetic retinopathy. Doc Ophthalmol 48: $363-371$

Received: 13 May 1981

and in revised form: 9 October 1981

Dr. J. I. Mann

Diabetes Research Laboratories

Radcliffe Infirmary

Woodstock Road

Oxford OX2 6HE, UK 